\title{
BELIEFS OF THE BIOLOGY TEACHERS ABOUT USING MULTIMEDIA
}

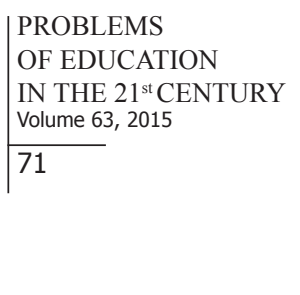

\author{
Tereza Odcházelová \\ Charles University in Prague, Czech Republic \\ E-mail: tereza.odchazelova@pedf.cuni.cz
}

\begin{abstract}
The Science disciplines suffer from neglect of the learners. Therefore, the teachers are looking for strategies how to increase the popularity and the efficiency of teaching biology. Biology as a discipline is suitable for using different kinds of visualization, including multimedia support as one of the possibilities for increasing the popularity of this subject. The implementation of multimedia in teaching process can be successful only if the teachers are aware of the needs and the advantages of these teaching aids. Confidence of the efficiency of application of multimedia support into the biology lessons was analysed by means of a questionnaire with the main focus on learning strategies and mental abilities of the learners. The questionnaire was distributed on-line in the Czech Republic to 422 teachers working at primary schools, secondary schools and high schools and to 222 pre-service biology teachers. Respondents identified the importance of using multimedia in everyday life. They determined many educational opportunities arising from the use of multimedia in education. According to their beliefs, the main roles of using multimedia are related to motivation, cognitive activity and learning activity. Besides, the teachers evaluate themselves as not very well experienced in using multimedia tools.

Key words: multimedia support of education, teacher's opinions about multimedia, motivation of learners, popularization of biology.
\end{abstract}

\section{Introduction}

Biology education contends with numerous problems. Many comparative studies of European standards (e.g., White Wolf Consulting, 2009; Younès, 2000) tried to detect the core of those deficiencies. One of the possible reasons for the lack of interest in biology by the learners is often no real connection of teaching biology as Science discipline with everyday life (Rochard et al., 2007) Thus, Rochard et al. (2007) notes total need of innovation in teaching methods and involvement of extracurricular activities to the educational process. Furthermore, there have been new discoveries and development in biology (botany, zoology, genetics, molecular biology, physiology, evolutionary biology etc.) and other natural sciences in recent years. Other modern and important topics of today are represented by global changes in terms of environmental, economic and multimedia concept. Biology education is often criticised for memorization of mass of scientific terms without understanding the core of the matter (Younès, 2000). Multimedia communication became a suitable tool for effective and attractive presentation of the recent research findings done in biology and natural sciences. The use of multimedia is based on conceptual knowledge of communication, which interfaces psychology, cognitive science and currently available technologies that enable multimedia communication (Vondra, 2014).

It is well known that multimedia technologies bring efficient communication of information in aspects of intensity, clarity, speed, or personal experience (Clark \& Paivio, 1991; Mayer \& Sims, 1994; Mayer \& Moreno, 2003). Because of these aspects the multimedia has highly changed the face of education and became a priority during the last decade (Joshi, 2011; Wastiau et al., 2013). Multimedia could undoubtedly represent quite powerful support for biology education (Advantages of Using ICT, 2014). It is especially because of its ability to clearly 
Tereza ODCHÁZELOVÁ. Beliefs of the biology teachers about using multimedia

PROBLEMS

OF EDUCATION

IN THE $21^{\text {st }}$ CENTURY

Volume 63, 2015

72

present new information which might be sometimes in this field of study very complex or a little bit tricky. The success of use of multimedia strongly relies on the way of their integration and way of application of their potential. The interest in multimedia and ICT in general has recently increased; therefore it is a significant research area for many scholars (Skutil, 2014). But also the opinion of the teacher while using multimedia for education is very important. The use of multimedia tools should be accepted only if the teachers are aware of the purposes and advantages deriving from such instruments (Fullan, 1991). Therefore, following the question has to be asked: Are the teachers convinced about the advantages of using multimedia? The facts mentioned above in connection with this question formed the main focus of this study. It deals with a variety of teachers' opinions about using multimedia in biology and it tries to find the foundation of using multimedia in biology based on those opinions.

\section{Problem of Research}

For this study it is necessary to define a couple of terms connected to multimedia. Multimedia learning, respectively multimedia teaching, takes place when the pupils record information presented by at least two different ways - for example visually presented animation and verbally presented explanation. Multimedia itself or multimedia support represent the technology which mediates multimedia learning and is available at schools - for example interactive whiteboards, tablets, computers, equipment for audio and video presentations etc. (Mayer, 2009).

Multimedia represents important support for education with high potential, but only when it is integrated in the right way. Mayer (2009, pp. 7-10) defines two approaches to multimedia learning: technology-centred and learner-centred. If the implementation of multimedia to educational processes wants to be successful, the technology has to be used for development of human learning. The machine-centred point of view has to be reversed and turned into a personcentred, hence the humans should not serve the technology, but the technology should serve the humans (Norman, 1993). For adequate multimedia teaching, the teacher should be skilled in using variety of multimedia. Additionally the teacher has to be strongly convinced about the advantages of multimedia support and also has to take in account its possible disadvantages.

Biology as a school subject is specific because nowadays it is almost impossible to teach biology without interdisciplinary perception of other natural sciences (Younès, 2000). New discoveries in this field of study are very often presented right through multimedia and it is something that cannot be ignored in education. Moreover, multimedia offers the possibility to clearly explain a number of complex biological principles. Computer animation supported by an appropriate commentary or additional interactive task can explain the principles that the pupils can later use for example during the Inquiry Based Science Education (Mayer, 2009). And, last but not least, biology can become more popular through proper use of multimedia, because sensory perception is characterized by the evocation of positive attitude towards learning. It has also been researched that using multimedia increases the level of information retention and shortens the learning time (Joshi, 2011). Therefore, biology teachers are the perfect group of potential respondents for the research focused on teachers' personal opinions about using multimedia in education.

\section{Research Focus}

Utilising of multimedia is one of the right ways how to make teaching biology more attractive and popular. Using multimedia activates the perception of pupils by engaging multiple senses and supports the nowadays so popular active learning (Mousavi et al., 1995; Fančovičová $\&$ Prokop, 2008). There are the researched data on one side, and the reality of what the teachers think about using multimedia as a teaching tool on the other side. According to Mackie \& Wylie (1988), the acceptance of technology is affected by different factors such as - the extent 
to which technology is consistent with the needs of users, users' awareness about the purpose of the technology or users' experience with the technology. The acceptance of multimedia as an educational support is easier when the teachers are aware of the advantages of multimedia tools (Fullan, 1991). Therefore the main aim of the research is to find out the opinions of the biology teachers and pre-service biology teachers about using multimedia in the lessons of biology.

At the beginning of this research there were a couple of essential questions that relate to the current discussion about the use of multimedia and communication technologies in biology education. Do the teachers of biology deem the multimedia as an appropriate teaching support? Do the opinions about using multimedia vary between the pre-service biology teachers and the teachers of biology? Are teachers of biology and pre-service biology teachers skilled in using multimedia?

\section{Methodology of Research}

\section{General Background of Research}

ICT and multimedia support is one of the driving elements of the current education. Biology, because of its particularity and need of visualisation, is a suitable school subject for application of multimedia. While applying new teaching methods and tools, including multimedia, the teacher has to be convinced about the advantages, otherwise the potential success is limited. Those facts formed the structure of this study which has two main parts: personal practice experiences of biology teachers and pre-service teachers of biology; opinions about application of multimedia into biology lessons. The quantitative research was applied in this study. The data collection lasted three months (October - December, 2014) and was realised through online questionnaire. The descriptive statistics was used and the opinions about using multimedia in biology were also analysed extra through factor analysis. Utilisation of factor analysis was considered as a suitable method for this type of data set.

\section{Sample of Research}

Teachers of biology and pre-service biology teachers were contacted by an e-mail and asked for their participation in this research. A total of 644 respondents participated in the study (422 teachers of biology, 222 pre-service biology teachers). Distribution of respondents is shown in Table 1. Participants' age ranged from less than 25 to more than 50 . Teachers who participated in the study worked in schools belonging to all of 14 regions of the Czech Republic. The pre-service biology teacher participants studied Biology Education at Faculty of Education or Faculty of Science, Charles University in Prague, Masaryk University in Brno, University of South Bohemia in České Budějovice and Palacký University in Olomouc. 
PROBLEMS

OF EDUCATION

IN THE $21^{\text {st }}$ CENTURY Volume 63,2015

Table 1. Distribution of 644 respondents who participated in the study: 422 biology teachers (teachers) and 222 pre service teachers (pre service teachers), figures show the number of respondents in each specific group.

\begin{tabular}{|c|c|c|c|c|c|c|c|c|c|}
\hline \multirow{3}{*}{$\begin{array}{l}\text { Teach- } \\
\text { ers }\end{array}$} & \multirow[b]{2}{*}{ Total } & \multicolumn{2}{|c|}{ Gender } & \multicolumn{6}{|c|}{ School type } \\
\hline & & Female & Male & $\begin{array}{l}\text { Special } \\
\text { basic school }\end{array}$ & $\begin{array}{l}\text { 1st stage of } \\
\text { elementary } \\
\text { school }\end{array}$ & $\begin{array}{l}\text { 2nd stage of } \\
\text { elementary } \\
\text { school }\end{array}$ & $\begin{array}{l}\text { General } \\
\text { secondary } \\
\text { school }\end{array}$ & $\begin{array}{l}\text { Secondary } \\
\text { technical } \\
\text { school }\end{array}$ & $\begin{array}{l}\text { Secondary } \\
\text { vocational } \\
\text { school }\end{array}$ \\
\hline & 422 & 310 & 112 & 11 & 31 & 185 & 142 & 37 & 16 \\
\hline \multirow{3}{*}{$\begin{array}{l}\text { Pre- } \\
\text { service } \\
\text { teach- } \\
\text { ers }\end{array}$} & \multirow{2}{*}{ Total } & \multicolumn{2}{|c|}{ Gender } & \multicolumn{6}{|c|}{ Degree of study } \\
\hline & & Female & Male & Bachelor's & & & Master's & & \\
\hline & 222 & 174 & 48 & & 154 & & & 68 & \\
\hline
\end{tabular}

\section{Instrument and Procedures}

All the above mentioned participants were contacted by e-mail with brief introduction explaining the aim of the study and what multimedia are (the simultaneous presentation of texts, pictures, animation, movies and sounds). Their participation in research was voluntary and anonymous. They were provided a link to an on-line questionnaire with closed questions and scale questions. The respondents were not given a time limit to fill the questionnaire in. The version of the questionnaire for teachers was divided into three parts - personal data, school practice questions, personal beliefs. The version of questionnaire for pre-service biology teachers consisted only of two parts - personal data, personal beliefs. Logically, the pre-service biology teachers were not asked about the questions from the school practice.

The school practice questions asked about the variety of multimedia used for biology education, its frequency of using and personal skills and experiences of the teachers. The part attended to personal beliefs was inspired by Antonietti \& Giorgetti (2004). Their questionnaire was reduced from 30 to 20 scale questions regarding the specifics of biology teaching. The questions discussed various psychological aspects of using multimedia in education and expressed a variety of statements about using multimedia in education. Those statements were arranged in the form of short sentences which are listed in Table 2 (they are listed in the order, which corresponds with the increasing values of the means of the teachers' scoring, whereas in the questionnaire they were listed in a different, random order). The subject of the sentence reported in each scale question was constantly "Using multimedia in biology lessons....". The respondent was asked to score on a 5-point ordinal scale (1=maximum; 5=minimum) his/her agreement about what was expressed in each statement. The points on scale correspond to the following concepts: 1 - I absolutely agree, 2 - I agree, 3 - I do not have crystallized opinion (I do not know), 4 - I do not agree, 5 - I absolutely do not agree.

\section{Data Analysis}

The data were processed with SPSS software for statistical data analysis. The main statistical procedures used for data analysis were descriptive statistics, chi-square test and factor analysis using Varimax rotation with Kaiser Normalization. Bartlett's test and Kaiser-MayerOlkin test were used to confirm the suitability of factor analysis. 


\section{Results of Research}

\section{Descriptive Statistics}

The opinions about using multimedia in biology of the respondents and their personal skills were analysed through descriptive statistics firs. Mean values and standard deviations of the scores of each scale question, computed on the whole sample are listed in Table 2. The answers (statements) are listed from the lowest to the highest mean score of the teachers. The value of the mean score shows whether the statements of the respondents are positive (low mean score) or negative (high mean score). The column chi-square shows the p-value of chi-square test. All chi-square tests have degree of freedom 4 . The p-value indicates the dependence, or independence of the answers of both groups of respondents - teachers and pre-service biology teachers ( $p$-value under 0.05 indicates dependence of the answers of both groups, $p$-value higher than 0.05 indicates independence). The values labelled with the star express statistically significant differences of proportion between groups. The following statements about using multimedia in biology lectures indicate the most statistically significant differences ( $p$-value 0.000) (Table 3): "Induces and facilitates making comparisons and links"; "Requires creativity of pupils"; "Requires high concentration of pupils"; "Distracts pupils from learning". The relative frequencies of scores related to the using of multimedia and concentration of the pupils ("Requires high concentration of pupils") express double top at pre-service biology teachers - they mainly chose slightly positive (value 2) or slightly negative (value 4) statements as contrasted to teachers who evaluate this statement more positively. This fact is also clear from mean values listed in Table 2 . The teachers are more sceptical about the statement that multimedia requires creativity of pupils, while more than $13 \%$ of pre-service biology teachers hugely agreed with this declaration. Most teachers are convinced that using multimedia in biology lectures does not distract pupils from learning, while the pre-service biology teachers are not so strongly convinced about that (Table 3 ).

Almost identical results of both groups of the respondents are expressed in case of the following statement "Using multimedia in biology lectures increases clarity of notions and thereby facilitates learning" as it is indicated by p-value 0.704 shown in Table 2 .

The respondents were asked about the necessity of using multimedia in everyday life. They also considered whether the ability to use multimedia and work with them is necessary for teachers and for pupils. Table 4 shows very interesting results, where there is a visible difference between the statements of the biology teachers and the pre-service biology teachers. The low scores of the mean value express positive statement, scores around 3 - mean neutral opinion, high scores state negative belief. Comparing to the statements of the pre-service biology teachers, the teachers from practice are more convinced about the importance of the ability of using multimedia, especially in case of necessity for teachers.

The analysis of the school practice questions (questions devoted to the personal practice of using multimedia technology) showed the lack of experience of the teachers with advanced multimedia tools (Table 5). Teachers graded themselves in different areas of using multimedia $(1=$ very good skills, $3=$ average skills, $5=$ very bad skills $)$. The mean scores showed that teachers feel very well skilled only in e-mail communication. They grade themselves well skilled in making presentations for educational support, social network using (e.g., Skype, Facebook, Twitter etc.) and also in data analysis and data interpretation (charts, tables etc.). Mean score around 3, which expresses average skills, is apparent in case of using multimedia technology for searching information and making presentations for interactive whiteboards. More advanced skills as working with video sequences and creating and application of e-learning in their lectures were graded 4 on average. Unfortunately, the pre-service biology teachers consider the university preparation for using multimedia technology in practice as deficient. According to their opinion, the study at their universities only develops personal computer literacy (writing documents, making presentations), whereas the connection with school practice is missing (Figure 1). 
Tereza ODCHÁZELOVÁ. Beliefs of the biology teachers about using multimedia

PROBLEMS OF EDUCATION IN THE $21^{\text {st }}$ CENTURY
Volume 63,2015

Table 2. Mean values and Standard Deviations recorded in each scale question of the whole sample (Total) and teachers (Teachers) and pre-service biology teachers (Pre-service teachers) separately; chi-square test (all with degree of freedom 4); p-value of chi-square (* p-value $<0.05$ ).

\begin{tabular}{|c|c|c|c|c|c|c|c|c|}
\hline \multirow{2}{*}{$\begin{array}{l}\text { Using multimedia in biology } \\
\text { lectures... }\end{array}$} & \multicolumn{2}{|c|}{ Teachers } & \multicolumn{2}{|c|}{$\begin{array}{l}\text { Pre-service } \\
\text { teachers }\end{array}$} & \multirow{2}{*}{$\begin{array}{l}\text { chi-square } \\
\text { test }\left(\chi^{2}=\right) \\
(\operatorname{df} 4)\end{array}$} & \multirow{2}{*}{$\begin{array}{l}p \text {-value of } \\
\text { chi-square } \\
\text { test }\end{array}$} & \multicolumn{2}{|l|}{ Total } \\
\hline & Mean & SD & Mean & SD & & & Mean & SD \\
\hline $\begin{array}{l}\text { Increases clarity of notions and } \\
\text { thereby facilitates learning. }\end{array}$ & 1.75 & 0.645 & 1.73 & 0.657 & 2.171 & 0.704 & 1.74 & 0.649 \\
\hline $\begin{array}{l}\text { Facilitates learning for pupils who } \\
\text { have a visual thinking style. }\end{array}$ & 1.88 & 0.611 & 1.82 & 0.737 & 16.156 & $0.003^{*}$ & 1.86 & 0.658 \\
\hline $\begin{array}{l}\text { Facilitates an understanding of } \\
\text { subject matter. }\end{array}$ & 1.94 & 0.629 & 2.04 & 0.766 & 7.976 & 0.092 & 1.97 & 0.680 \\
\hline $\begin{array}{l}\text { Is attractive and arose pupils' } \\
\text { motivation. }\end{array}$ & 2.04 & 0.690 & 2.00 & 0.810 & 8.859 & 0.065 & 2.02 & 0.733 \\
\hline $\begin{array}{l}\text { Makes notions for pupils more } \\
\text { convincing and credible. }\end{array}$ & 2.10 & 0.814 & 2.13 & 0.930 & 4.407 & 0.354 & 2.11 & 0.855 \\
\hline $\begin{array}{l}\text { Makes application of learned no- } \\
\text { tions easier. }\end{array}$ & 2.14 & 0.705 & 2.18 & 0.794 & 4.198 & 0.380 & 2.15 & 0.737 \\
\hline $\begin{array}{l}\text { Facilitates learning for pupils with } \\
\text { special needs. }\end{array}$ & 2.14 & 0.738 & 2.12 & 0.843 & 10.274 & $0.036^{*}$ & 2.13 & 0.775 \\
\hline $\begin{array}{l}\text { Helps pupils to clarify complex } \\
\text { concepts and think about them. }\end{array}$ & 2.18 & 0.685 & 2.26 & 0.873 & 12.705 & $0.013^{*}$ & 2.20 & 0.755 \\
\hline Makes notion memorization easier. & 2.19 & 0.705 & 2.19 & 0.831 & 7.055 & 0.133 & 2.19 & 0.750 \\
\hline Allows pupils to learn fast. & 2.26 & 0.746 & 2.33 & 0.870 & 8.764 & 0.067 & 2.28 & 0.791 \\
\hline $\begin{array}{l}\text { Induces and facilitates making } \\
\text { comparisons and links. }\end{array}$ & 2.27 & 0.708 & 2.38 & 0.928 & 22.815 & $0.000^{*}$ & 2.31 & 0.792 \\
\hline Induces pupils to be active. & 2.43 & 0.882 & 2.38 & 0.989 & 11.217 & 0.704 & 2.41 & 0.920 \\
\hline $\begin{array}{l}\text { Facilitates learning for pupils who } \\
\text { tend to think schematically. }\end{array}$ & 2.46 & 0.744 & 2.55 & 0.875 & 13.687 & $0.008^{*}$ & 2.49 & 0.792 \\
\hline $\begin{array}{l}\text { Facilitates learning for pupils with } \\
\text { rapid loss of attention. }\end{array}$ & 2.51 & 0.797 & 2.36 & 0.940 & 19.602 & $0.001^{*}$ & 2.46 & 0.851 \\
\hline $\begin{array}{l}\text { Allows pupils to learn with no effort } \\
\text { and in an implicit way. }\end{array}$ & 2.61 & 0.845 & 2.47 & 0.891 & 9.203 & 0.056 & 2.56 & 0.863 \\
\hline Requires creativity of pupils. & 2.69 & 0.895 & 2.56 & 1.056 & 23.811 & $0.000^{*}$ & 2.65 & 0.955 \\
\hline $\begin{array}{l}\text { Requires high concentration of } \\
\text { pupils. }\end{array}$ & 2.87 & 0.898 & 2.98 & 1.063 & 23.290 & $0.000^{*}$ & 2.91 & 0.959 \\
\hline Is tiring for pupils. & 3.72 & 0.748 & 3.73 & 0.768 & 7.723 & 0.102 & 3.72 & 0.754 \\
\hline Distracts pupils from learning. & 3.85 & 0.741 & 3.52 & 1.032 & 31.561 & $0.000^{*}$ & 3.74 & 0.866 \\
\hline $\begin{array}{l}\text { May be confusing and could lead } \\
\text { to misunderstanding. }\end{array}$ & 3.94 & 0.814 & 3.77 & 1.015 & 13.852 & $0.008^{*}$ & 3.88 & 0.891 \\
\hline
\end{tabular}


Table 3. Contingency tables of relative frequency of the statements in cases of chi-square test with $\mathrm{p}$ value 0.000 ; all values are expressed as percent.

\begin{tabular}{|c|c|c|c|}
\hline Using multimedia in biology lectures... & $\begin{array}{l}\text { Level of agreement } \\
\text { (1=max., } 5=\text { min.) }\end{array}$ & Teachers & Pre-service teachers \\
\hline \multirow{5}{*}{ Requires high concentration of pupils } & 1 & 3.8 & 8.1 \\
\hline & 2 & 35.1 & 30.2 \\
\hline & 3 & 32.7 & 19.8 \\
\hline & 4 & 27.3 & 39.2 \\
\hline & 5 & 1.2 & 2.7 \\
\hline \multirow{5}{*}{ Distracts pupils from learning } & 1 & 0.2 & 0.2 \\
\hline & 2 & 5.2 & 5.2 \\
\hline & 3 & 18.7 & 18.7 \\
\hline & 4 & 60.7 & 60.7 \\
\hline & 5 & 15.2 & 15.2 \\
\hline \multirow{5}{*}{ Requires creativity of pupils } & 1 & 5.7 & 13.1 \\
\hline & 2 & 41.5 & 45.0 \\
\hline & 3 & 32.0 & 17.1 \\
\hline & 4 & 19.4 & 22.1 \\
\hline & 5 & 1.4 & 2.7 \\
\hline \multirow{5}{*}{$\begin{array}{l}\text { Induces and facilitates making comparisons } \\
\text { and links }\end{array}$} & 1 & 9.5 & 15.8 \\
\hline & 2 & 59.2 & 44.6 \\
\hline & 3 & 26.5 & 27.0 \\
\hline & 4 & 4.3 & 11.3 \\
\hline & 5 & 0.5 & 1.4 \\
\hline
\end{tabular}

Table 4. The statements about the necessity of using multimedia - mean values recorded in the whole sample of biology teachers (Teachers) and preservice biology teachers (Pre-service teachers) separately.

\begin{tabular}{llll}
\hline & $\begin{array}{l}\text { Mean of } \\
\text { teachers }\end{array}$ & $\begin{array}{l}\text { Mean of } \\
\text { pre-service } \\
\text { teachers }\end{array}$ & $\begin{array}{l}\text { p-value of } \\
\text { chi-square }\end{array}$ \\
\hline Using of multimedia technology is necessary for everyday life & 1.71 & 2.09 & 0.001 \\
\hline The ability to use multimedia and work with them is necessary for pupils. & 1.73 & 2.27 & 0.000 \\
\hline $\begin{array}{l}\text { The ability to use multimedia and work with them is necessary for teach- } \\
\text { ers. }\end{array}$ & 1.55 & 2.12 & 0.000 \\
\hline
\end{tabular}


Tereza ODCHÁZELOVÁ. Beliefs of the biology teachers about using multimedia

PROBLEMS

OF EDUCATION

IN THE $21^{\text {st }}$ CENTURY

Volume 63, 2015

78

Table 5. Self-grading of the teachers' skills in different areas of using multimedia on five point scale $(1=$ very good skills, $3=$ average skills, $5=$ very bad skills).

\begin{tabular}{|c|c|c|c|}
\hline & Mean & & Mean \\
\hline E-mail communication & 1.34 & Social network using (Facebook, Twitter, Skype etc.) & 1.90 \\
\hline Information search using variety of sources & 3.04 & Making presentations for interactive whiteboards & 3.11 \\
\hline Making presentations & 1.73 & Working with video sequences & 4.07 \\
\hline $\begin{array}{l}\text { Data analysis and interpretation (texts, tables, } \\
\text { charts) }\end{array}$ & 2.14 & Making e-learning & 3.94 \\
\hline $\begin{array}{l}\text { It prepairs us } \\
\text { within didactics } \\
\text { of biology }\end{array}$ & & $\begin{array}{l}\text { Pevelops only } \\
\text { personal } \\
\text { "computer } \\
\text { literacy" }\end{array}$ & \\
\hline
\end{tabular}

Figure 1: Opinions of the pre-service biology teachers about the university preparation for using multimedia in school practice.

Factor Analysis

To find the behind hidden factors and detect the structure of the statements, the factor analysis was inducted. Factor analysis using Varimax rotation with Kaiser Normalization led to extract, as suggested by Scree test, four different factors. Scree plot (Figure 2) shows, that first component expresses $35.14 \%$ of variance, the second one only $8.17 \%$, third one $6.77 \%$ and the fourth component expresses $5.78 \%$ of the variance. All the components express $55.87 \%$ of variance in total. To determine the correctness of the choice of statistical method (factor analysis) the Kaiser-Meyer-Olkin Measure of Sampling Adequacy (KMO) and Bartlett's test were inducted. As it is shown in Table 6, the KMO reach the value between 0 and 1 . The result 0.916 indicates the suitability of factor analysis for the data set of this study. Further confirmation of the suitability of factor analysis is the result of the Bartlett's test (Table 6).

The resulting rotated matrix is reported in Table 7 . Factor 1 is loaded by items about learning processes, Factor 2 concerns the cognition, Factor 3 can be labelled as motivation. Factor 4 includes the negative statements about multimedia. Those negative beliefs, shown by Factor 4, criticize multimedia comparing to the others and are provided by both groups of respondents.

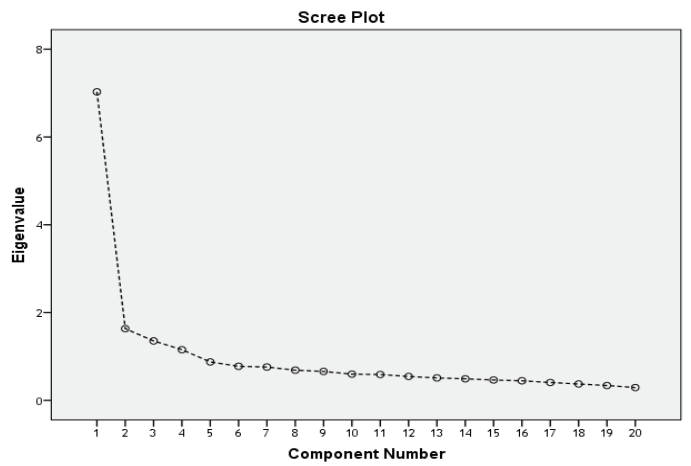

Figure 2: Scree Plot of Factor Analysis showing the expression of variance; $x$ axis expresses component number; $y$ axis shows eigenvalues. 
Table 6. Results of Kaiser-Mayer-Olkin test (KMO) and Bartlett's test showing the correctness of the choice of statistical method - factor analysis for the dataset of this study.

\begin{tabular}{lll}
\hline Kaiser-Meyer-Olkin Measure of Sampling Adequacy. & & 0.916 \\
\hline \multirow{3}{*}{ Bartlett's Test of Sphericity } & Approx. Chi-Square & 4666.148 \\
\cline { 2 - 3 } & $\mathrm{df}$ & 190 \\
\cline { 2 - 3 } & Sig. & 0 \\
\hline
\end{tabular}

Table 7. Factorial structure of the personal beliefs (scores of each scale question) of the whole sample of respondents after Varimax rotation.

\begin{tabular}{|c|c|c|c|c|}
\hline \multirow{2}{*}{ Using multimedia in biology lectures... } & \multicolumn{4}{|c|}{ Factor } \\
\hline & 1 & 2 & 3 & 4 \\
\hline Induces and facilitates making comparisons and links. & 0.792 & & & \\
\hline Helps pupils to clarify complex concepts and think about them. & 0.769 & & & \\
\hline Facilitates an understanding of subject matter. & 0.599 & & & \\
\hline Makes notion memorization easier. & 0.596 & & & \\
\hline Allows pupils to learn fast. & 0.590 & & & \\
\hline Makes application of learned notions easier. & 0.529 & & & \\
\hline Facilitates learning for pupils who tend to think schematically. & 0.471 & & & \\
\hline Makes notions for pupils more convincing and credible. & 0.413 & & & \\
\hline Facilitates learning for pupils who have a visual thinking style. & & 0.710 & & \\
\hline Facilitates learning for pupils with special needs. & & 0.686 & & \\
\hline Increases clarity of notions and thereby facilitates learning. & & 0.648 & & \\
\hline Facilitates learning for pupils with rapid loss of attention. & & 0.596 & & \\
\hline Allows pupils to learn with no effort and in an implicit way. & & 0.498 & & \\
\hline Requires creativity of pupils. & & & 0.782 & \\
\hline Induces pupils to be active. & & & 0.766 & \\
\hline Requires high concentration of pupils. & & & 0.659 & \\
\hline Is attractive and arose pupils' motivation. & & & 0.455 & \\
\hline May be confusing and could lead to misunderstanding. & & & & -0.755 \\
\hline Distracts pupils from learning. & & & & -0.740 \\
\hline Is tiring for pupils. & & & & -0.674 \\
\hline
\end{tabular}


Tereza ODCHÁZELOVÁ. Beliefs of the biology teachers about using multimedia

\author{
PROBLEMS \\ OF EDUCATION \\ IN THE $21^{\text {st }}$ CENTURY \\ Volume 63,2015

\section{Discussion}

The teachers identify multimedia technology as a teaching tool which might support their pedagogical ideas if it is used in accordance with their personal beliefs (Kynäslahti, 2002). In fact, the effects of multimedia are mediated by teachers' beliefs about its role in learning. Therefore, it is important to consider what teachers think about multimedia (Antonietti \& Giorgetti, 2006). Biology teachers and pre-service biology teachers were chosen for this study because of the specifics of Biology as a school subject. It is one of the most suitable subjects for application of multimedia because of the following reasons: the necessity of linking biology to real everyday life; the need of visualization while explaining biological principles; request of the pupils for popularization biology and natural sciences; necessity to accept modern technologies, etc. The sample of analogous research realised by Antonietti \& Giorgetti (2006) consisted mainly of the teachers from kindergarten and primary school, therefore the focus of this study was different.

What do teachers think about using multimedia in biology lessons? Do they accept multimedia technology as useful teaching aid? And are they skilled in using this type of support of education? Those were the major questions for the research. The biology teachers and pre-service biology teachers were asked about their beliefs and statements concerning what multimedia instructional support could stimulate in the pupils' mind. Their personal experiences of using multimedia were also researched.

According to Clark (2001), major part of the respondents recognized positive effects of multimedia (Table 2). The teachers and pre-service teachers of biology are strongly convinced especially about the ability of multimedia to increase clarity of notions which facilitates learning. The respondents also considered strong acceptance of the possibility of facilitating learning through multimedia for pupils who have visual thinking style (Table 2). Both of those statements correspond to numerous recent researches (e.g., Mayer, 2009; Joshi, 2011; Skutil, 2014), but also the researches from last decades (Clark \& Paivio, 1991; Mayer \& Sims, 1994). Multimedia uses multisensory perception, therefore demonstratively more comprehensive knowledge is created, which makes information more acceptable and it is preserved longer (Clark \& Paivio, 1991). Analogously, if a principle is explained, the combination of visual and verbal presentation increases the probability of understanding of this principle and the suitability of eventual application in practice (Mayer \& Sims, 1994). These are the facts which have to be taken in account also in teaching process and it is very important, that biology teachers are familiarised with that. Considerable result for application of multimedia in biology is also the disagreement of both groups of respondents with statements which criticised the multimedia.

Previous case studies showed that teachers' opinions concerned mainly motivation and involvement, cognitive activity and facilitation and optimization (Antonietti \& Giorgetti, 2006). This study also identifies three similar issues of respondents' opinions about using multimedia in biology (Table 7). Those issues are dedicated to motivation (Factor 3): multimedia are perceived to increase creativity, activity and motivation of the pupils; learning process (Factor 1): multimedia are related to making comparisons and links, multidisciplinary thinking, faster and easier learning; cognition and the capability of multimedia for pupils with different needs of learning strategies (Factor 2). Factor 4, the negative statements about multimedia (distraction, tiredness and confusion), can be related to the issues of cognition and learning process. Several links between the research of Antonietti \& Giorgetti (2006) and the results of the present investigation can be drawn.

Different opinions appeared between the two groups of respondents: biology teachers; pre-service biology teachers. The results indicated differences especially in opinions connected with practical knowledge of teaching process (Table 3). Basically the opinions of the teachers attributed to multimedia more positive properties. The pre-service biology teachers were more restrained. This may be caused by lack of experience of pre-service biology teachers with active learning. Their statements were logically based on their personal beliefs and probably only on their own earlier experiences as pupils. 
Another significant and surprising result of this study is represented by different opinions about the necessity to use multimedia and work with them (in everyday life and in school practice). Pre-service biology teachers are not as strongly convinced about the need of multimedia as the teachers are. This was quite unpredictable. The pre-service biology teachers are younger than teachers from practice. More affection of pre-service teachers to ICT and multimedia would be expected. But the modern time and the development of technologies makes multimedia and working with them essential, including its use in educational process (Younès, 2000). The teachers already know the practice and are influenced by reality. The teachers are also strongly expected to use multimedia. Logically, they consider multimedia as important. Both groups of respondents feel multimedia and working with them important for pupils. This opinion corresponds with the study of Fančovičová \& Prokop (2008) which was focused on the attitudes of pupils toward computer use.

On the other hand, the teachers feel weaknesses of their personal skills in this field. They grade themselves as poorly educated in the use of more advanced types of multimedia (Table 5) as making presentations for interactive whiteboards or e-learning. Unfortunately, according to the pre-service biology teachers, the university preparation for using multimedia in school practice is poor (Figure 1). The university preparation of pre-service biology teachers takes in account only their personal skills of using ICT. It should be focused more on the real utilization of multimedia in school practice.

Gender differences in attitudes towards the computers are often reported (e.g., Oosterwegel, Littleton \& Light, 2004; Volman \& Van Eck, 2001). Gender possibly affects the general attitude towards technologies, but it does not have to mean gender differences in opinions about the sense of using multimedia in education. This study failed to find gender differences in multimedia attitudes within the respondents analogous to Antonietti \& Giorgetti (2006). They suggest that teachers, irrespectively of their gender, are facing the same educational problems, are involved in the same practices, are trained according to the same pedagogical principles etc. This leads them to developing similar conceptions about the instructional tools.

For the future research it is important to test the pupils' perceptions and beliefs about using multimedia technology in biology and natural sciences. The beliefs of the specific biology teacher have to be taken into account, because the major impression about multimedia support of the pupils can be influenced by the impression of their teacher.

\section{Conclusions}

The biology is suitable for application of multimedia because of high necessity of visualization and the need of explanation of complex principles. For successful use of multimedia in school practice, the teachers have to believe in it. Hence the study focused on the opinions of biology teachers and pre-service biology teachers.

According to the factor analysis, three main roles of using multimedia by teachers and pre-service teachers can be distinguished, i.e. motivation, learning activity and cognitive activity. The respondents attribute to multimedia the ability of increasing pupils' motivation, creativity and activity. Biology teachers as well as pre-service biology teachers think, that multimedia are related to making comparisons and links, multidisciplinary thinking and faster and easier learning. They also consider multimedia as a suitable support for pupils with different and/or special needs of learning strategies. The respondents reject all negative statements about using multimedia in biology (distraction, tiredness and confusion). The opinions about using multimedia do not eminently vary between pre-service biology teachers and teachers of biology. One difference was found about the opinions connected with practical knowledge of teaching process. The teachers of biology were more positive about using multimedia support in biology. The gender differences were not indicated.

Similarly the obtained results show, that the teachers themselves do not feel very well skilled in using more advanced multimedia technologies, e.g. interactive whiteboards and its 
Tereza ODCHÁZELOVÁ. Beliefs of the biology teachers about using multimedia

PROBLEMS

OF EDUCATION

IN THE $21^{\text {st }}$ CENTURY

Volume 63, 2015

software or e-learning. Besides the pre-service biology teachers note, that the university preparation is focused only on their personal skills of using ICT, but does not follow the real utilization of multimedia in school practice.

\section{Acknowledgements}

The author would like to thank to Aneta Hybšová (Charles University in Prague, Faculty of Education) and Petr Mazouch (University of Economics, Prague, Department of Economic Statistics) for their assistance with data analysis. The study was supported by the grant projects of the Charles University in Prague (PRVOUK P 15 and SVV: 260 108/2014).

\section{References}

Advantages of Using ICT in Learning-Teaching Processes (2014). Retrieved March 15, 2014, from http://edtechreview.in/trends-insights/insights/959-advantages-of-using-ict-in-learning-teachingprocesses

Antonietti, A., \& Giorgetti, M. (2006). Teachers' beliefs about learning from multimédia. Computers in Human Behavior, 22, 267-282.

Clark, J. M., \& Paivio, A. (1991). Dual coding theory and education. Educational Psychology Review, $3(3), 149-210$.

Clark, R. E. (Ed.). (2001). Learning from media: Arguments, analysis, and evidence (Vol. 1). IAP.

De Witte, K., \& Rogge, N. (2014). Does ICT matter for effectiveness and efficiency in mathematics education? Computers \& Education, 75, 173-184. doi: 10.1016/j.compedu.2014.02.012.

Fančovičová, J., \& Prokop, P. (2008). Students' attitudes toward computer use in Slovakia. Eurasia Journal of Mathematics, Science \& Technology Education, 4 (3), 255-262.

Fullan, M. (2007). The new meaning of educational change. Routledge.

Joshi, A. (2011). Innovative teaching: Using multimedia in a problem-based learning environment. Current World Environment: An International Research Journal of Environmental Science, 6 (1), $183-186$

Kynäslahti, H. (2002). University teachers' conceptions of teaching in the context of the use of ICT: A crucial element for the implementation of educational technology. Paper presented at the Annual Conference of the European Distance Education Network (EDEN), Granada (Spain).

Mackie, R. R., \& Wylie, C. D. (1988). Factors influencing acceptance of computer-based innovation. In M. Helander (Ed.), Handbook of human-computer interaction (pp. 1081-1106). New York: Elsevier.

Mayer, R. (2009). Multimedia learning. New York: Cambridge University Press.

Mayer, R. E., \& Moreno, R. (2003). Nine ways to reduce cognitive load in multimedia learning. Educational Psychologist, 38 (1), 43-52.

Mayer, R. E., \& Sims, V. K. (1994). For whom is a picture worth a thousand words? Extensions of a dual-coding theory of multimedia learning. Journal of Educational Psychology, 86 (3), 389-401.

Mousavi, S. Y., Low, R., \& Sweller, J. (1995). Reducing cognitive load by mixing auditory and visual presentation modes. Journal of Educational Psychology, 87 (2), 319-334.

Norman, D. A. (1993). Things that make us smart: defending human attributes in the age of the machine. New York: Addison-Wesley Publishing Company.

Oosterwegel, A., Littleton, K., \& Light, P. (2004). Understanding computer-related attitudes through an idiographic analysis of gender- and self-representations. Learning and Instruction, 14, 215-233.

Rochard M., Csermely P., Jorde D., Lenzen D., Walberg-Henrikson H., Hermmo U. (2007) Science education now: A renewed pedagogy for the future of Europe. Brussels: European Comission, Directorate-General for Research, Science, Economy and Society, Information and Communication Unit. 22 pp.

Skutil, M. (2014). ICT as one of the teaching methods at primary school from a teacher's point of view. Problems of Education in the 21st Century, 61, 105-112.

Volman, M., \& Van Eck, E. (2001). Gender equity and information technology in education: The second decade. Review of Educational Research, 71, 613-634.

Vondra, Z. (2014). Multimédia jako nástroj využití informace uchované v kulturním dědictví. Culturologia. 1 (3), 14-20. 
Wastiau, P., Blamire, R., Kearney, C., Quittre, V., Van de Gaer, E., \& Monseur, C. (2013). The use of ICT in education: A survey of schools in Europe. European Journal of Education, 48, 11-27. doi:10.1111/ejed.12020.

White Wolf Consulting (2009). Důvod nezájmu žáků o přirodovědné a technické obory. Retrieved 17/02/2015, from http://www.generacey.cz/duvody-nezajmu-zaku-o-prirodovedne-a-technickeobory.

Younès T. (2000) Biological education: Challenges of the 21st century. Biology International, (39), 8-13. Retrieved 18/02/2015, from http://www.iubs.org/pdf/publi/BI/BI\%20Numero\%2039. pdf\#page $=10$.

Advised by Vincentas Lamanauskas, Šiauliai University, Lithuania

Received: February 03, 2015

Accepted: February 20, 2015

Tereza Odcházelová

PhD. Student, Department of Biology and Environmental Studies, Faculty of Education, Charles University in Prague, Czech Republic. E-mail: tereza.odchazelova@pedf.cuni.cz 